\title{
健康食品素材の有效性評侕及び健康影響評侕に 関する研究
}

\author{
石見 佳子
}

国立研究開発法人医薬基盤・健康・栄養研究所 国立健康 · 栄養研究所食品保健機能研究部

\begin{abstract}
【目的】健康食品は人びとの日常生活で利用されてきているが，その有効性と安全性について科学的根拠に乏しいものも市場に出回つ ている。筆者らは, 食の安全確保を目的として, 特に骨及び関節に関連する健康食品素材について, 有効性評価及び健康影響評価を 行った。

【方法】健康食品素材を骨粗鬆症または関節症モデル動物に混飹により摂取させ，28日間反復投与試験を実施した。一部の素材につい ては，国立健康・栄養研究所倫理委員会の承認を得て，閉経後女性を対象に無作為割付比較試験を実施した。

【結果】大豆イソフラボンについては, 動物試験において骨に対する作用と生殖器官に対する作用で用量依存性が異なること, ヒトを 対象とした介入試験において, 骨に対する作用の一部はその代謝産物であるエクオールの産生に依存することが明らかになった。一 方, ビタミンKについては, 健常な閉経後女性において, 骨の健康維持の観点からは不足している可能性があること, さらにメナキノ ン-4 の摂取により, 骨代謝が改善される可能性が示唆された。コラーゲンペプチド, メチルスルホニルメタン, スピルリナ, レスベラ トロールについては，過剩摂取は避けるべきであることが示された。

【結論】今般, 新たな機能性表示食品制度が創設されたことを踏まえると, 健康食品の有効性評価及び健康影響評価は, レギュラトリー サイエンスの領域の中で引き続き重要な課題であると考えられた。これらの研究は，消費者の食の安全確保につながるものである。
\end{abstract} 栄養学䧱誌, Vol.74 No.5 117-127 (2016)

キーワード： 健康食品，保健機能食品制度，有効性評価，健康影響評価，レギュラトリーサイエンス

\section{I .はじめに}

近年, 人びとの健康意識の高まりと, 食品の機能性研 究の発展から, 健康食品の利用が増えている。健康食品 とは「健康に何らかの良い効果があると期待される様々 な食品の総称」と理解されているが，その名称に法的根 拠はない。健康食品の変遷としては, 1984年, 文部科学 省の重点研究「食品の機能性研究」が開始され, 食品の 機能性に関する研究が進んだことに始まる（図 1 )。その 後, 高齢社会の到来による消費者の健康意識の高まり等 からその利用が高まったが，こうした状況のなか，健康 食品に関する不確かな情報が汇濫したことから，1991 年, 当時の厚生省は, 消費者に正しい情報に基づき食品 を選択できるよう，国の制度として，特定保健用食品制 度を創設した。特定保健用食品は, 健康増進法の下, 当 該食品の有効性と安全性を個別に評価し, ある特定の保 健の用途を表示するものである。その後2001年，米国か らの要請もあり, 規制緩和の観点から, ビタミン・ミネ ラルを対象として栄養素の機能表示をする栄養機能食品 が創設され，特定保健用食品と合わせて保健機能食品と 位置付けられた。さらに2015年，政府の規制緩和政策の
「健康食品」とは、健康に何等かの良い効果が あると期待される様々な食品の総称 （名称に法的根拠はない）

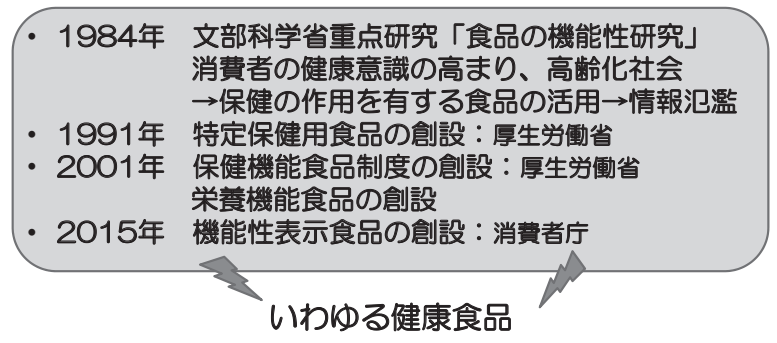

図 1 「健康食品」の変遷

下，食品表示法に基づき機能性表示食品制度が創設され 現在に至っている。このような国による機能性を持つ食 品の表示制度が創設されてきているが，これまでこれら の枠組みに当てはまらない「いわゆる健康食品」が存在 してきている。本稿では，筆者が1995年より2015年にか けて実施した，科学的根拠が十分でない骨及び関節系に 係る健康食品素材について, その有効性評価及び健康影 響評価を行った成果について，特に大豆イソフラボンを 中心に概説する。 


\section{II. 大豆イソフラボン}

\section{1. 社会的背景}

1997年, シーア・コルボーン著の「奪われし未来」が 出版され, ダイオキシン等の残留性化学物質等による世 代を超えた健康影響が社会問題として大きく取り上げら れた。また，同年，NHK 特集において環境污染物質に よる魚のメス化が報道され, これらの化学物質は「内分 泌かく乱物質」と命名され広く一般に知られるに至っ た。これらの物質のなかには植物由来のエストロゲン様 作用を示す物質も含まれている。古くより，アルファル ファを大量に摂取した羊が不妊を呈することが報告され ており，植物由来のエストロゲン様物質の健康影響が報 告されていたが，1994年，閉経前女性を対象とした大豆 たんぱく質の介入試験が米国で実施され，卵胞期が延長 することが報告された1)。次いで，1996年には同様の介 入試験が実施され，大豆たんぱく質の摂取により，閉経 前女性の血中のエストラジオールが低下することが報告 された2)。一方, 同年, Arjmandi らは, 大豆たんぱく質 を骨粗鬆症モデルラットに摂取させると骨量減少が抑制 されることを報告した $(\text { 図 } 1)^{3)}$ 。これらの作用は, 大豆 に含まれる弱いエストロゲン様作用を示すイソフラボン に起因するものではないかと考えられた。当時，筆者ら は骨粗鬆症の予防を目的とした栄養学的研究を実施する 中で，骨芽細胞を用いてビタミン $\mathrm{A}$ 誘導体， $\mathrm{n}-3$ 系脂肪 酸，大豆イソフラボンをスクリーニングしていた。そこ で大豆イソフラボンの女性ホルモン様作用に着目し, そ の有効性評価及び健康影響評価を実施した。図 2 に，こ れまでの大豆イソフラボン研究の経緯を示す。
2. 大豆イソフラボンの有効性評価及び健康影響評価

\section{1) 動物試験}

大豆イソフラボンは大豆の肧軸部分に多く含まれる成 分で，配糖体のダイジン，ゲニスチン，グリシチン及び アグリコンのダイゼイン，ゲニステイン，グリシテイン が存在する (図 3 )。また, 配糖体には上記の他, マロニ ル配糖体，アセチル配糖体，サクシニル配糖体がある。 イソフラボンは，大豆の種子には主に配糖体として存在 しており，ヒトが摂取した場合は腸管内でアグリコンと なって吸収される。筆者らは，大豆イソフラボンが弱い 女性ホルモン様作用を示すことから，骨粗鬆症モデルマ ウスを作製して，子宮と骨に対する影響を評価した。そ の結果，大豆イソフラボンは骨粗鬆症モデルマウスの骨 量減少を抑制すること ${ }^{4)}$ ，骨に対する作用の10倍量で子 宮重量を増加させることが明らかになった（図 4 ) ${ }^{5)}$ 。子 宮への影響は, 病理組織学的解析によっても確認し, 骨 に作用する量では子宮に影響しないことを確認した5)。

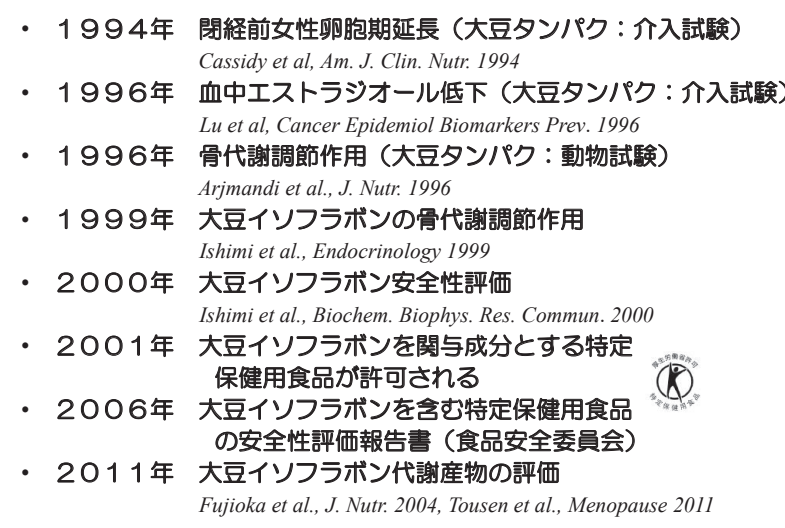

図 2 大豆イソフラボン研究

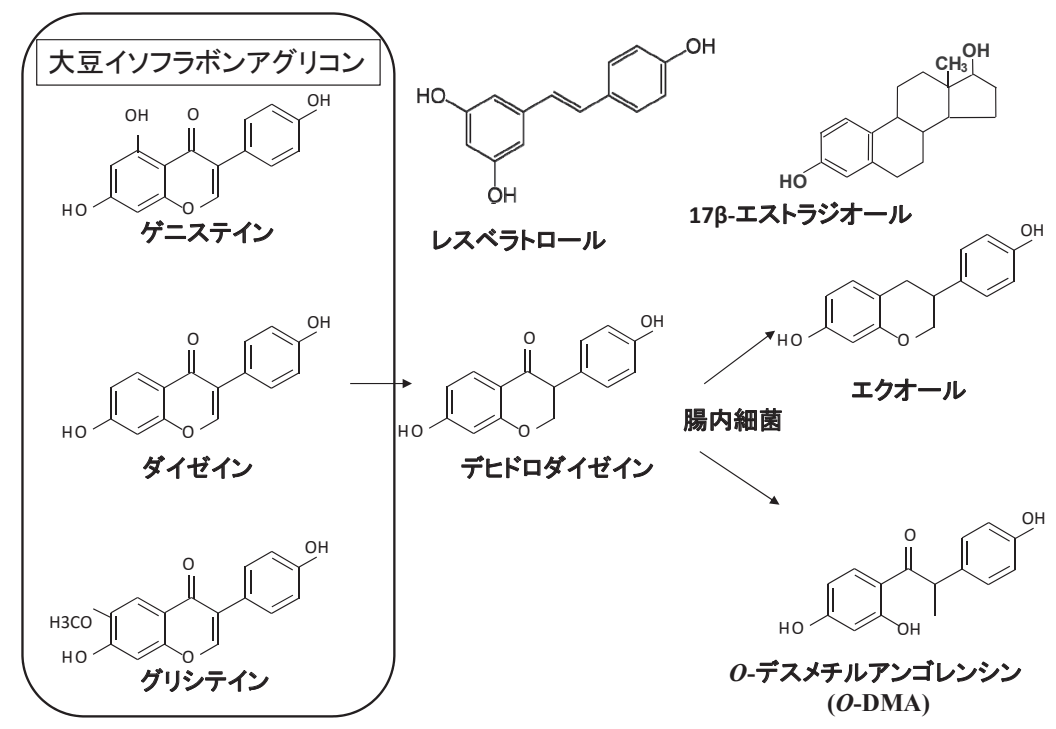

図 3 主な大豆イソフラボンとその代謝産物, エストロゲン, レスベラトロー ルの化学構造 
イソフラボンの作用が組織によって異なるのは，おそら くエストロゲン受容体の多様性によるものと考えられ る。すなわち, 骨組織では主に $\beta$ 受容体が, 子宮では $\alpha$ 受容体が発現していることから， $\beta$ 受容体により親和性 の強い大豆イソフラボンは, 骨に対する作用がより低用 量で発現するものと考えられた。

2 ）ヒトを対象とした試験

次に筆者らは, 閉経後 5 年以内の健常な閉経後女性 136 名を対象に, 1 年間の大豆イソフラボン含有食品（フジ フラボン $\mathrm{P} 40$, フジッコ社製) のプラセボ対象無作為割 付比較試験（RCT）を実施した。その際, 両群において 運動負荷群を設定し, 運動との併用効果についても検討 した。その結果，大豆イソフラボン摂取単独（アグリコ ン換算 $47 \mathrm{mg}$ ）では骨量減少に対する効果は軽微であっ

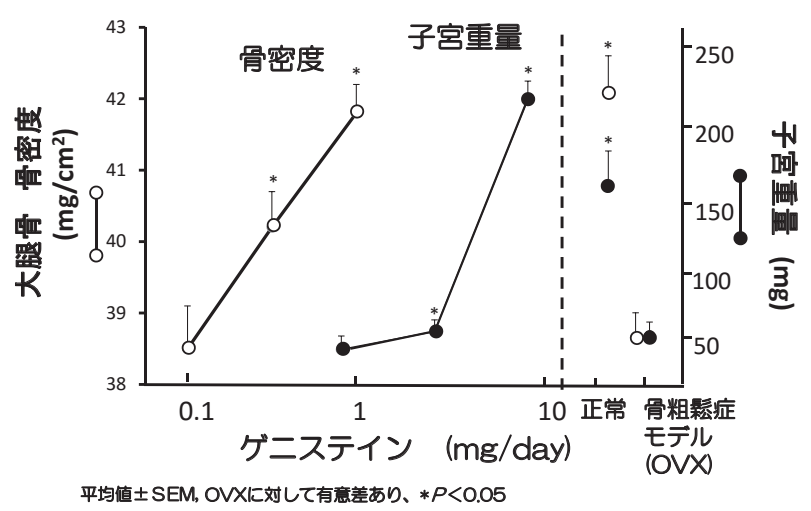

図 4 大豆イソフラボンの骨粗鬆症モデルマウスの骨密度と 子宮重量に対する影響 : 用量依存性試験

文献 5 ）より改編
たが, 週 3 回（1 回45分）のウォーキングとの併用は, 閉経後女性の骨量減少を抑制する可能性が示された。こ の際，血中エストロゲン濃度への影響は認められなかっ た。一方，ダイゼインは腸内細菌によって，よりエスト ロゲン活性の強いエクオールに代謝されることが報告さ れていたことから, 対象者のエクオール産生能を指標 に，イソフラボンの骨に対する効果を層別解析した。エ クオール産生者は全体の $55 \%$ であり，産生者において は，非産生者に比べてより効果的に骨量減少が緩和され る作用が認められた (図 5$)^{6)}$ 。血中のイソフラボン濃度 を評価したところ，ダイゼイン，ゲニステイン，グリシ テインの血中濃度は, 対照群及びイソフラボン摂取群と もにエクオール産生者と非産生者間で有意な差は認めら れなかったが，血中のエクオール濃度はエクオール産生 者のみで検出され，イソフラボン摂取群における血中濃 度は，対照群に比べて有意に高值を示した（図 6$)^{6,7) 。 ~}$ これらのことより，イソフラボンの骨への作用の一部 は，エクオール産生能の有無に依存する可能性が示唆さ れた。

3 ）食品安全委員会による大豆イソフラボンの安全性 評価

2001年，大豆イソフラボンは「骨の健康が気になる方」 のための特定保健用食品の関与成分として許可された が，アグリコン型イソフラボンからなる錠剤型の食品が 申請されたことを受けて, 食品安全委員会は, 大豆イソ フラボンの安全性について評価を行った。2006年に発出 された食品安全委員会の報告書では, 特定保健用食品と して摂取する大豆イソフラボンアグリコンの安全な一日
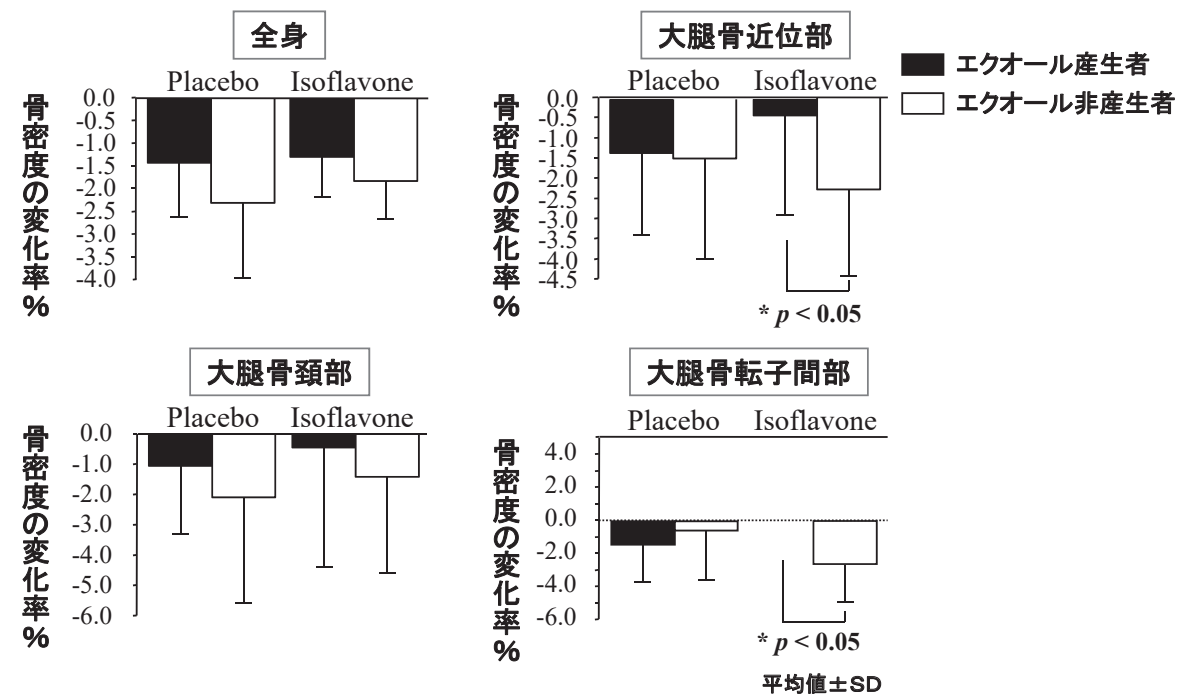

図 5 閉経後女性を対象とした 1 年間の大豆イソフラボン介入試験：エクオール産生能 に着目した骨密度の年間変化率

文献 6 ）より改編 
上乗せ摂取量の上限として $30 \mathrm{mg}$ また，大豆イソフラ ボンアグリコンの安全な一日摂取目安量の上限は $75 \mathrm{mg}$ とされた (図 7$)^{8)}$ 。乳幼児や妊婦, 授乳婦の摂取は推奨 しないとされた。さらに今後の研究課題として, ダイゼ インの代謝産物であるエクオールに関するデータは限ら れており,さらなる検討が必要であるとされた。なお, 食品安全委員会の大豆イソフラボン評価報告書には, 筆 者らの骨と子宮への作用の用量依存性の違いに関する動 物試験の報告5) 及び大豆イソフラボン摂取時の血中エク
オール濃度に関するヒト試験の報告7) が引用された。

4 ）エクオールの有効性評価及び健康影響評価

筆者らは, 次にエクオールの有効性及び健康影響を評 価するため, 骨粗鬆症モデルマウスにエクオールを摂取 させ，骨量と子宮重量に対する影響を評価したところ， 他の大豆イソフラボンと同様に，エクオール摂取は子宮 重量に影響することなく骨量減少を抑制することが明ら かになった 9 。 。また，大妻女子大学の池上幸江教授との 共同研究で, 妊娠期及び授乳期の母親ラットにダイゼイ
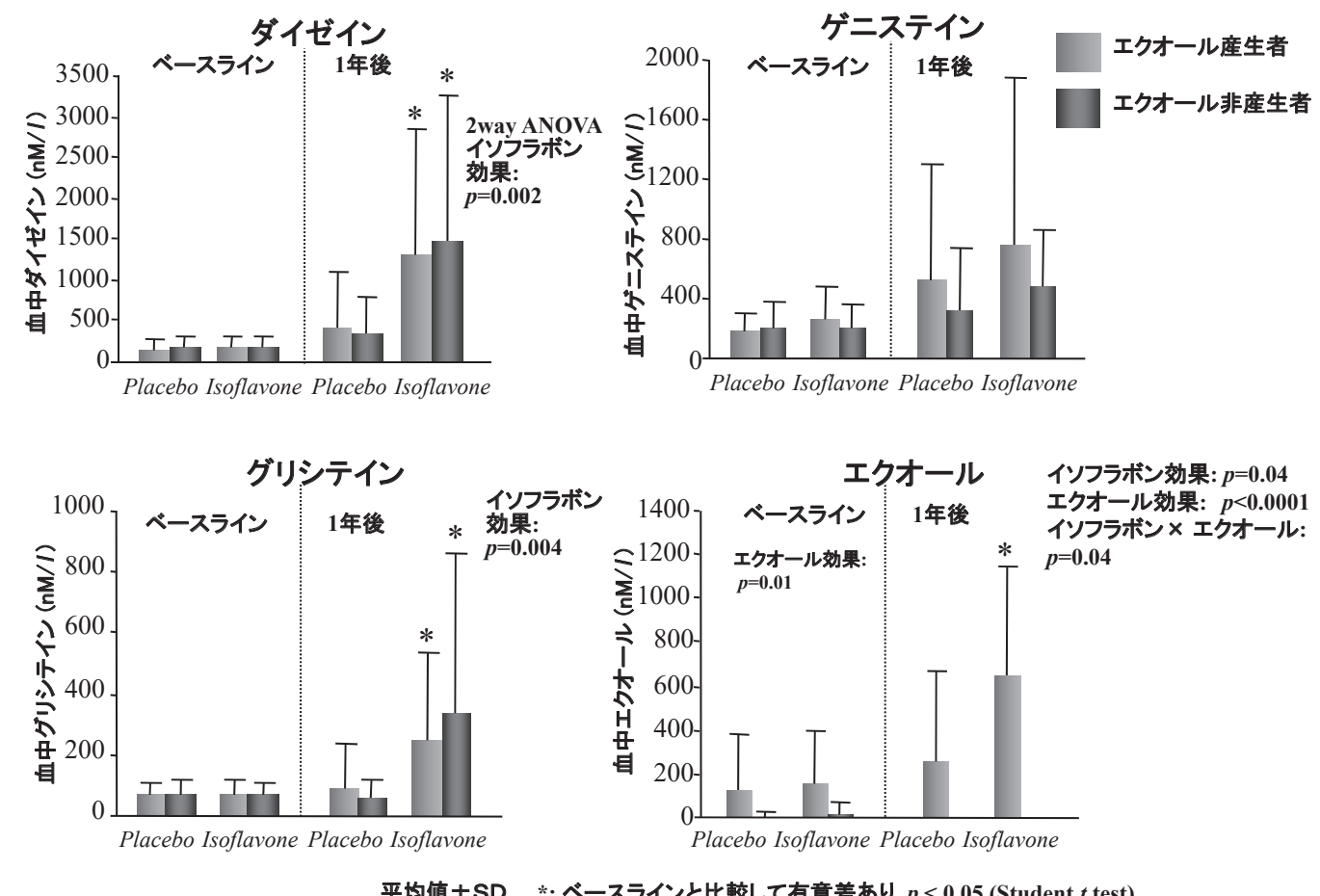

平均値士SD， *: ベースラインと比較して有意差あり, $p<0.05$ (Student $t$ test)

図 6 閉経後女性を対象とした 1 年間の大豆イソフラボン介入試験 : エクオール産生能に着目したイ ソフラボンの血中濃度

文献 6 ）ょり改編

閉経前女性·閉経後女性、及び男性

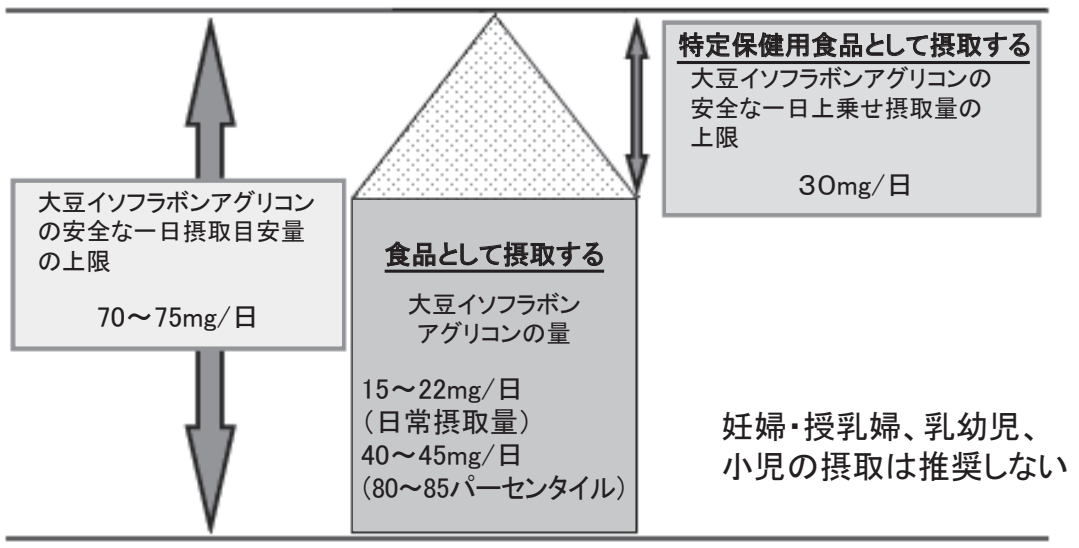

図 7 大豆イソフラボンを含む特定保健用食品の安全性評価の基本的な考え方

文献 8 ) より 
ンを摂取させると, 乳仔ラットの胃内にエクオールが検 出されたことから, エクオールは母親からの授乳を介し て仔ラットに移行することが判明した (図 8$)^{10)}$ 。この 時, ダイゼイン摂取群は対照群に比べて仔ラットの体重 増加が有意に抑制された。この結果は, 妊娠期及び授乳 期に大豆イソフラボンを摂取することは推奨しないとい う食品安全委員会の報告を支持するものである。

次に，エクオールを産生しない閉経後 5 年以内で健常
な日本人女性120名を対象に，2 10 mg のエクオールを 含有する大豆発酵食品の二重盲検プラセボ対象 RCT を 実施した。その結果，エクオール $10 \mathrm{mg}$ を含む大豆発酵 食品を 1 年間摂取した群において，骨吸収の指標である 尿中のデオキシピリジノリン濃度が対照群に比べて有意 に低值を示し，摂取終了 1 か月後には対照群と同等のレ ベルに戻った (図 9$)^{11)}$ このことから，エクオール含有 大豆発酵食品の摂取により, 閉経後女性の骨からのカル

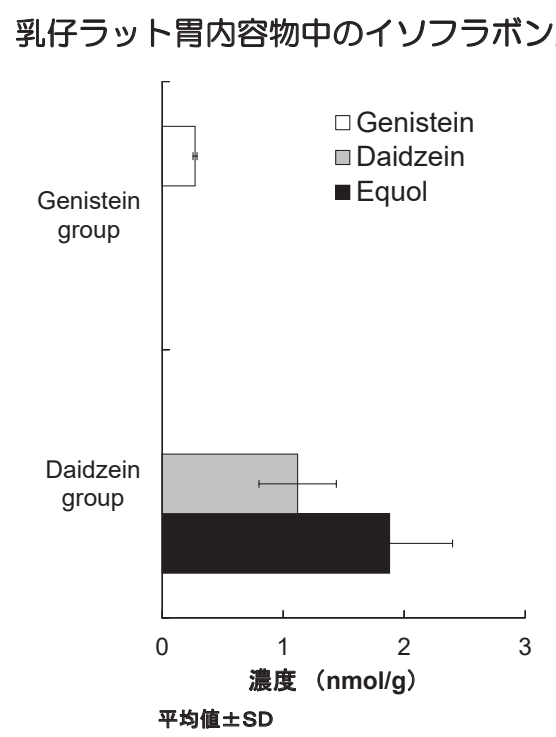

仔ラット体重の経過変化

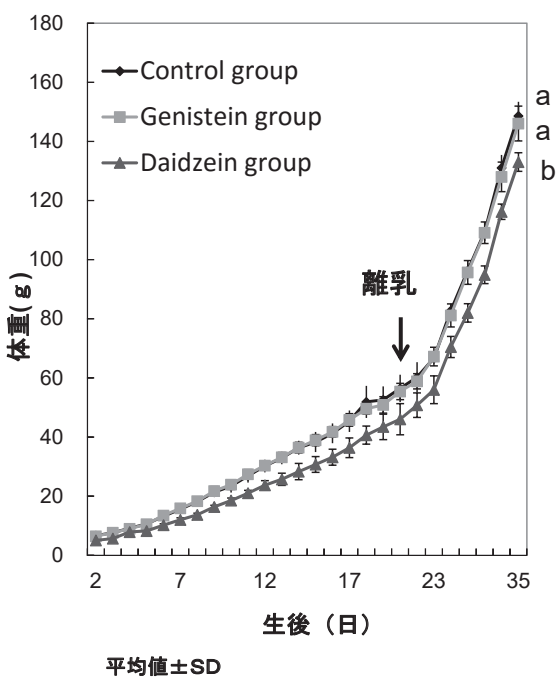

図 8 妊娠期及び授乳期の母親ラットが摂取した大豆イソフラボンは授乳を介して仔 ラットに移行する

文献10）ょり改編

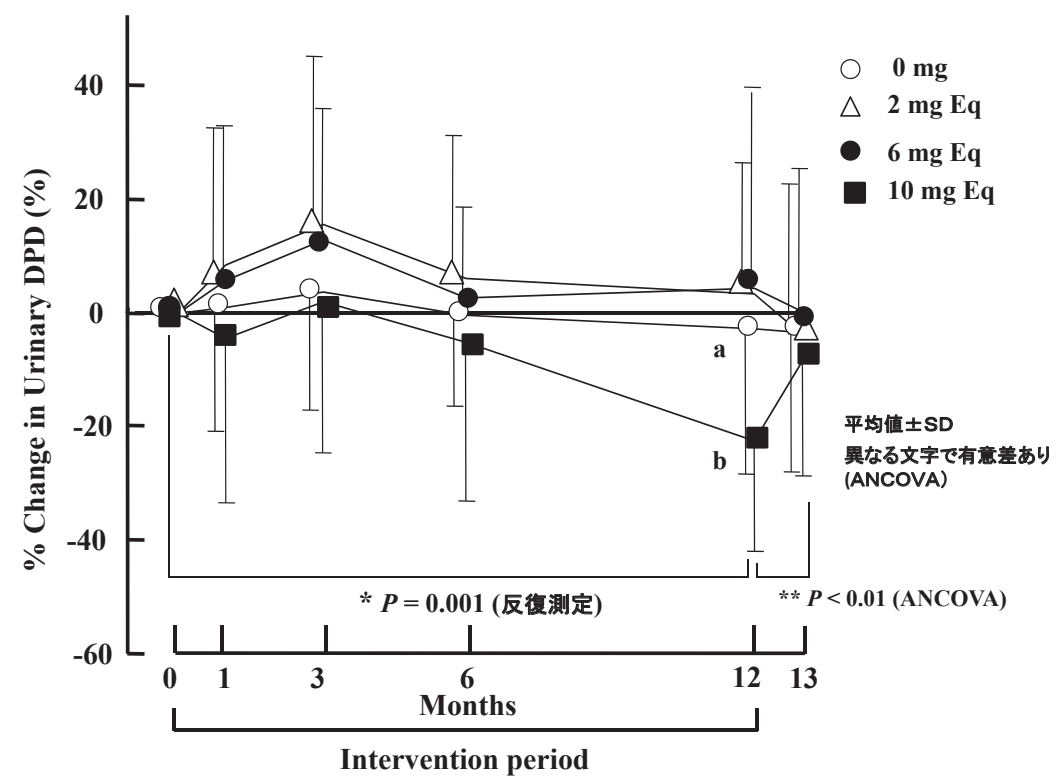

図 9 エクオール含有大豆発酵食品の摂取が閉経後女性の尿中骨吸収マーカー に及ぼす影響

文献11）より改編 


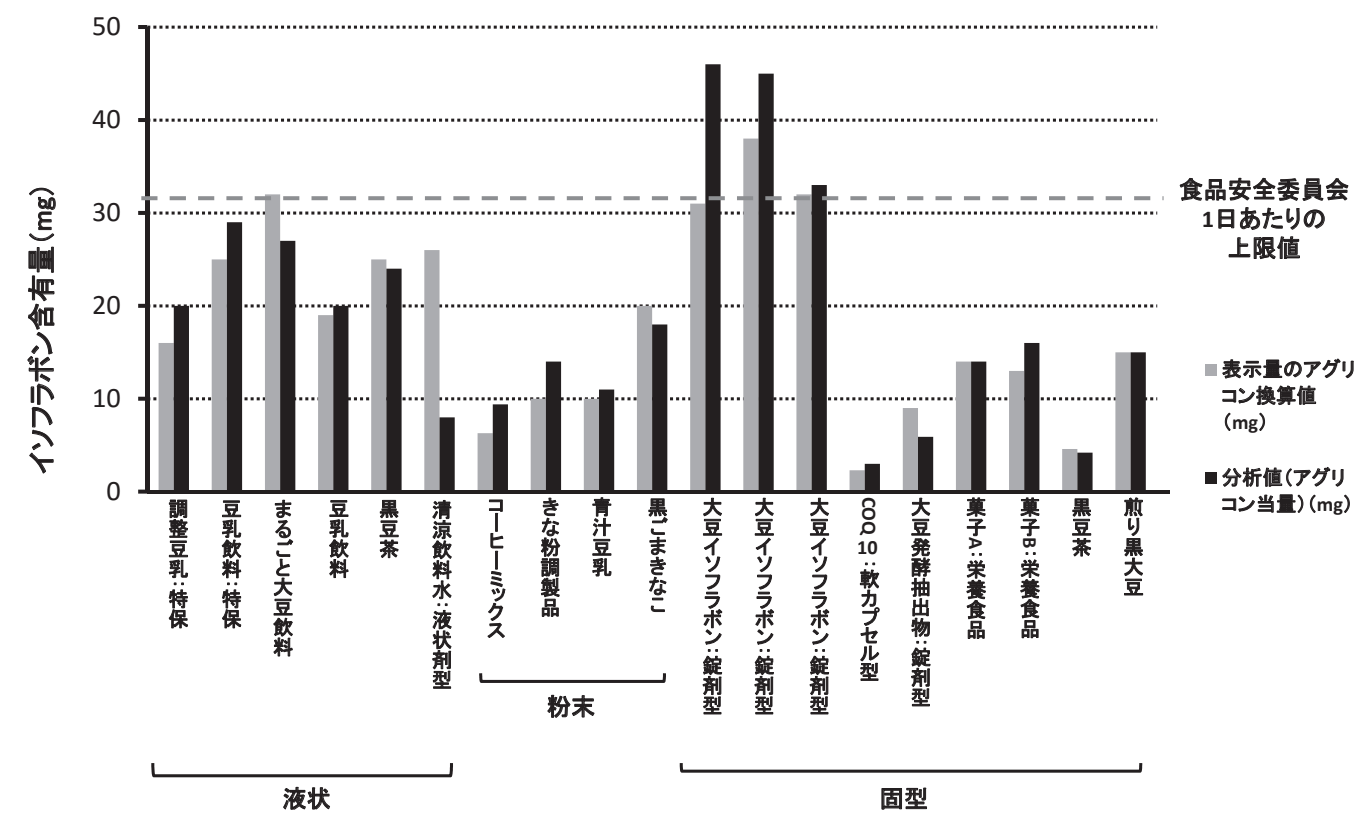

図10 健康食品中の大豆イソフラボン（アグリコン）含有量：1 日または 1 回摂取目安量に関する表 示值との比較

文献13）より改編

シウムの溶出が抑えられたことが示唆された。なおここ の際, 血中エストロゲン, FSH, LH ならびに甲状腺ホ ルモン（T3, T4, Free）の濃度に影響はなかった。また, 対象者の 24 時間畜尿中のエクオールを定量したところ平 均 $20 \mu \mathrm{M}$ であり, 健常な日本人 1,345 名の尿中エクオー ル濃度 $28.9 \pm 42.1 \mu \mathrm{M}$ の範囲内であったことから, 閉経 後女性に扔いては $10 \mathrm{mg}$ のエクオール摂取は, 現時点で は打そらく安全であることが示唆された ${ }^{12)}$ 。

5 ）健康食品中の大豆イソフラボンの定量分析 2006年, 食品安全委員会の報告書を受けて, 厚労省は 特定保健用食品のみならず，大豆イソフラボンを濃縮・ 強化した錠剤, カプセル状, 粉末剂, 液剤の健康食品に ついて, 大豆イソフラボンアグリコンの 1 日撖取目安量 の上限を $30 \mathrm{mg}$ とする通知を発出したことは先にも述べ た。そこで筆者らは, 市場にある健康食品中の大豆イソ フラボン含有量を把握するため, 飲料, 粉末状, 錠刻型 及びカプセル型の健康食品を市場から入手し, 表示值と 分析值を比較した（図10）。その結果, 錠剂型の健康食品 では，1日摂取目安量中のイソフラボンアグリコンの含 有量が $30 \mathrm{mg}$ を超えるものが散見された13,14)。また, 輸 入の錠剂型の食品には15種類のイソフラボンのうち, ゲ ニステインのみで構成されているものが存在した ${ }^{15)}$ 。こ れらのことから, 大豆イソフラボンを含む健康食品には その構成成分が異なるものや含有量が多いものが存在す ることが明らかになった。このように, 大豆イソフラボ ンを含む健康食品は, その含有量や組成について違いが
あることから，吸収性や生体利用性が製品によって異な る可能性が示唆された。

\section{III. 骨・関節を対象とした健康食品素材の有効性評 価及び健康影響評価}

筆者らは，以下に記載する骨・関節に関連する健康食 品素材について，ヒトが健康食品から摂取する量の 1 〜 100倍量を体重または体表面積で換算して正常ラットまた は関連する疾病モデルマウスに混飳摂取させ，28日間の 反復投与試験を実施した。

1.コラーゲンペプチドの安全性と骨代謝調節作用の 評価

コラーゲンは皮䖉，血管，骨に存在するたんぱく質で 生体を構成するたんぱく質の $30 \%$ を占めている。ゼラチ ンやにかわの原料であり，古くから食材として利用され ている。コラーゲンが熱によって変性したものがゼラチ ンで，ゼラチンをさらに加水分解して分子量を数千程度 まで小さくしたものがコラーゲンペプチドである。近 年, 様々な分子量のものが健康食品素材として利用され ている。そこで筆者らは, 予弤カルシウム食 $(0.2 \%)$ で 9 週間飼育した 32 週齢正常 Wistar 系雄性ラットに 1 100倍量のコラーゲンペプチド（I 型，新田ゼラチン社製 SCP-5000）を摂取させ， 8 週間の反復投与試験を実施し た。その結果, 摂取目安量 $10 \mathrm{~g} /$ 日 $(0.16 \mathrm{~g} / \mathrm{kg} \mathrm{BW} /$ day $)$ の100倍量において腎臟の肥大が認められた。その他の臓 


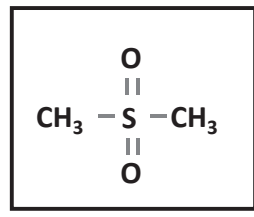

MSMの構造式

\begin{tabular}{|c|}
\hline $\begin{array}{l}\text { STR-Cont群：関節症マウス普通食群 } \\
\text { MSM1群： } 50 \mathrm{mg} / \mathrm{kg} \text { BW/day MSM摄取群 } \\
\text { MSM10群： } 500 \mathrm{mg} / \mathrm{kg} \mathrm{BW} / \mathrm{day} \text { MSM摂取群 } \\
\text { CBA群： } \\
\text { 対照群 }\end{array}$ \\
\hline $\begin{array}{l}\text { 関節炎スコアは、変形性膝関節症の特徴 } \\
\text { (滑膜肥厚, 半月板損傷, 関節軟骨表面損 } \\
\text { 傷, 骨棘形成)についてスコア化した(9点 } \\
\text { 満点)。 }\end{array}$ \\
\hline
\end{tabular}

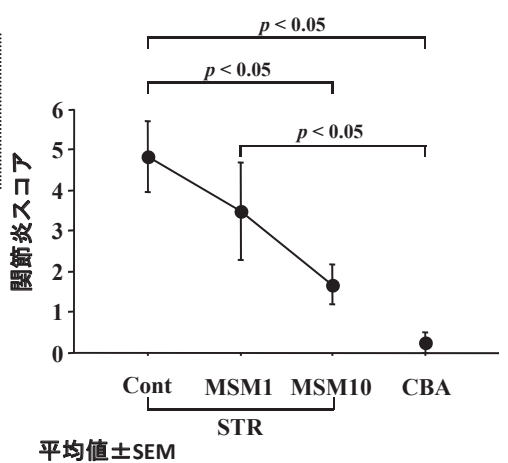

図11 自然発症変形性膝関節症モデルマウスの後肢膝関節の関節炎スコアに対す るメチルスルフォニルメタン（MSM）摂取の影響

文献17）より改編

器重量, 肝機能マーカー, 組織学的解析結果において異 常は認められなかった。脂質代謝については，1～100倍 量のコラーゲンペプチドの摂取により，血中トリグリセ リドの有意な低下が認められた。骨代謝については，摂 取目安量の10倍量のコラーゲンペプチドの摂取により, 対照群に比べて大腿骨及び腰椎の骨密度が高值を示し, これはコラーゲン無添加正常カルシウム食 $(0.5 \%)$ で飼 育したラットと同等であった。これらのことから, コ ラーゲンペプチドの NOAEL は摂取目安量の10倍量（100 g/日）程度であり，過剩摂取は避けるべきであること， カルシウムが不足している状態では骨代謝を正に調節す る可能性が示唆された16)。

2.メチルスルフォニルメタン摂取の安全性と骨・軟 骨形成に対する有効性評価

メチルスルフォニルメタン（MSM）はジメチルスルホ ン $\left(\mathrm{DMSO}_{2}\right)$ としても知られる天然由来の有機イオウ化 合物の一種であり，ジメチルスルフォキシド（DMSO） の酸化物である。食物では穀類, 果物, 野菜, 牛乳など に含まれている。近年 MSM は関節炎や美容に対する効 果を標榜したいわゆる健康食品素材として, 単独もしく はグルコサミンやコンドロイチン硫酸塩などと混合した 形で市販されている。しかし, その安全性や有効性につ いては十分に検討されていない。筆者らは, 成長期 Wistar 系雄性ラットを用いて MSM (Kirin Aspro 社製) の28日間反復投与試験を行ったところ, ヒトが通常, 健 康食品から摂取する最大量 $3 \mathrm{~g} / \mathrm{day}(60 \mathrm{mg} / \mathrm{kg}$ BW/day） では MSM 摂取による影響はみられなかったが，その10
倍及び100倍量では腎臓および骨組織に異常が認められ た。また, 自然発症変形性膝関節症モデルマウス（STR/ Ort）を用いた28日間反復投与試験では，10倍量の MSM の摂取で脾蔵重量の低下が認められた。骨および軟骨に 及ぼす影響については10倍量の MSM 摂取により，関節 炎スコアは用量依存的に低下し，10倍量では対照群 (CBA マウス）と同程度であった（図11）。このことから MSM の摂取は, 関節の炎症を緩和する可能性が示唆さ れるが，過剩摂取に留意する必要があることが明らかに なった ${ }^{17)}$ 。

\section{3.スピルリナの安全性と有効性評価}

スピルリナは藻類の一種で, 微細藻類藍菌門に属す る。中米やアフリカのアルカリ塩水湖に広く自生し, ク ロロフィルを持ち光合成を行う。1970年代に紹介されて 以来, その栄養の豊富さから「未来の食糧」などとして 注目を浴びたが，近年では同じ微細藻類であるクロレラ と並んでいわゆる健康食品として市販されているが，そ の安全性や有効性については十分に検討されていない。 そこで18週齢 Wistar 系骨粗鬆症モデルラット及び 8 週齢 $\mathrm{dd} \mathrm{Y}$ 系後肢非荷重モデルマウスを用いて，スピルリナ （東洋酵素社製）の安全性評価及び骨代謝への影響につい て評価した。その結果, ヒトが通常, 健康食品から摂取 する最大量 $4.8 \mathrm{~g} /$ day $(80 \mathrm{mg} / \mathrm{kgBW} /$ day $)$ からその 100 倍量のスピルリナ摂取により，両モデルとも摂取群にお いて大腿骨の骨密度が対照群と比較して有意に低值を示 した。骨粗鬆症モデルラットにおいては, スピルリナの 過剩摂取により，血中カルシウムが低值を示したことか 
対象: 年齢50 65歳の閉経後女性80名 介入: VK(MK-4) $1.5 \mathrm{mg} /$ 日 4週間 評価: 血中オステオカルシン(OC)

低カルボキシル化OC

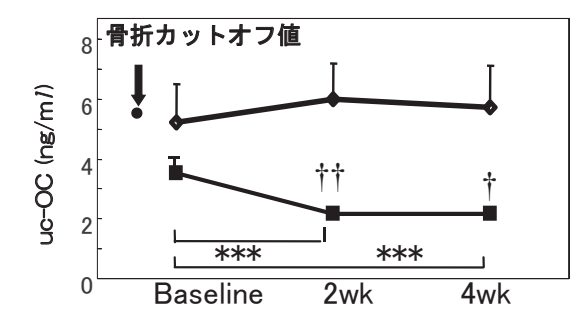

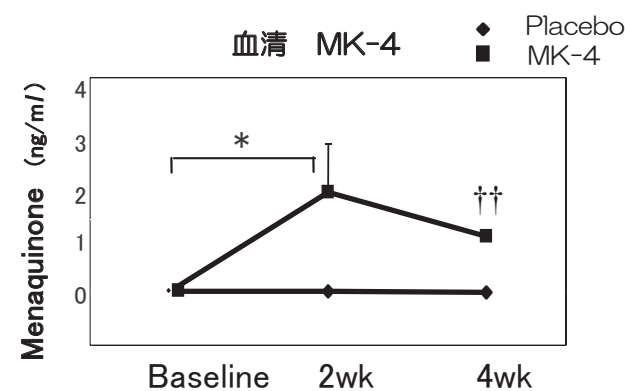

$r$ カルボキシル化OC/総OC比

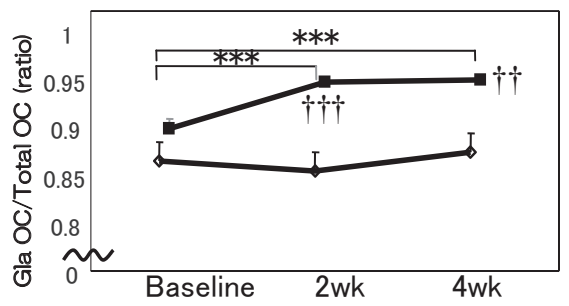

平均值士SD, *** $p<0.001$ (Repeated-measures ANOVA), $\uparrow p<0.05, \dagger+p<0.01, \dagger \dagger p<0.001$ vs. Placebo (Unpaired t-test)

図12 閉経後女性を対象としたビタミン K2（MK-4）の介入試験：血清オステオカルシン濃度 の変化

文献19）より改編

ら，腸管からのカルシウム吸収に影響を及ぼす可能性が 示唆された18)。また, 骨粗鬆症モデルラットでは, 1 ～ 100倍量のスピルリナの摂取により血中トリグリセリドの 低下が認められた。

\section{4. ビタミン K2（MK-4）摂取が閉経後女性の骨代謝} に及ぼす影響

ビタミン K は骨形成に寄与するオステオカルシンの活 性化において重要な役割を果たす。オステオカルシンは

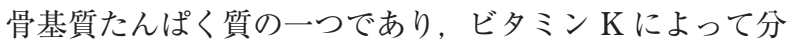
子内のグルタミン酸残基の $\gamma$ 位がカルボキシル化 (Gla) されて活性型となり, カルシウムと結合することで骨形 成に寄与する。一方, ビタミン K はコラーゲンの遺伝子 発現を直接促進することで，骨基質たんぱく質の合成に も関与している。疫学研究では, ビタミン K の摂取量と骨 折の発生率が負の相関を示すことが報告されていること から，ビタミン K は骨質により強く影響を及ぼすと考え られている。日本人の食事摂取基準（2015年版）におけ るビタミン $\mathrm{K}$ の目安量は, 血液凝固に対する作用を維持 する量として，国民健康・栄養調査の結果から納豆を捸 取していない者の平均的な摂取量とされている（成人男 女 $150 \mu \mathrm{g} /$ 日)。しかし, 閉経後日本人女性の骨代謝にお けるビタミン $\mathrm{K}$ の必要量は明確にされていない。筆者ら は, 80 名の健常な閉経後日本人女性（平均年齢59.5 5.4 歳) を対象として, ビタミン $\mathrm{K}_{2}$ (メナキノン $-4: \mathrm{MK}-4$ ) の二重盲検プラセボ対象無作為割付比較試験を実施した ところ, ビタミン K の栄養状態を示す低カルボシキルオ
ステオカルシン（ucOC）は，試験開始時において骨折発 症のカットオフ值 $(5.5 \mathrm{ng} / \mathrm{ml})$ を上回っていた ${ }^{19)} 。$ MK-4（1. $5 \mathrm{mg}$ /日）錠菓（協和発酵キリン社製）の 4 週 間の介入により, ucOC は低下し，活性型のオステオカ ルシン $(\mathrm{GlaOC})$ は増加した $\left(\right.$ 図12) ${ }^{19)}$ 。次に, 健常な閉 経後日本人女性（平均年歯58. $4 \pm 3.8$ 歳）を対象に， 1 年 間の MK-4（1.5 mg/日）とカルシウム（200 mg/日）を 含有する食品の介入試験を実施したところ，ucOC の低 下と共に，対照群では前腕骨の骨密度が低下したが, MK-4 摂取群では変化はなかった ${ }^{20)}$ 。なお， 3 日間の食 事調査では，対象者のビタミン K の摂取量は 166〜182 $\mu \mathrm{g} /$ 日であり，食事摂取基準の目安量（150 $\mu \mathrm{g} /$ 日）から はビタミン $\mathrm{K}$ の摂取量は十分であると判断された。これ らのことから, 閉経後女性の骨代謝を正常に保つビタミ ン $\mathrm{K}$ の必要量は，食事摂取基準で設定されている目安量 より高い可能性が示唆された。疫学研究では, 高齢者は 若年者に比べて, ビタミン $\mathrm{K}$ の必要量が高まっていると 報告されている21）。以上より，健常な閉経後女性の骨代 謝においては，ビタミン $\mathrm{K}$ が不足している可能性がある ことが示唆された。

\section{5.レスベラトロールの安全性評価}

レスベラトロールは抗加齢効果を示す健康食品素材と して注目され, 健康寿命やアンチエイジング志向の成分 として飛躍的に注目が高まっている。レスベラトロール はふどうの皮等に含まれるポリフェノールの一種で，抗 酸化作用, 抗腫瘍作用等が報告されている。一方で, レ 
スベラトロールを含むこれらの健康食品は, 含有成分な どの品質の規格基準はあるものの, その食品成分自体の 安全性に関する科学的根拠はそしい。また，エストロゲ ン欠乏時のレスベラトロール摂取の安全性に関する評価 はほとんどされていない。そこで筆者らは, レスベラト ロールの安全性に関して肝臓の薬物代謝系酵素に着目 し，閉経後骨粗鬆症モデル動物を用いて検討した。その 結果, ヒトが健康食品から摂取する量 $80 \mathrm{mg} /$ 日（17 $\mathrm{mg} / \mathrm{kgBW} /$ 日）のレスベラトロール（Sigma 社製）摂取 は, 骨粗鬆症モデルマウスの体重や肝臓重量に顕著な影 響を与えなかったが, DNA マイクロアレイ解析の結果, 肝臓の薬物代謝酵素である Cyp4a10, Cyp2d1, Cyp2b9, Cyp2e1 の遺伝子発現が対照群と比較し有意に低值を示し た。大腿骨骨密度はすべての群間で有意な差は認められ なかった。これらの結果より, エストロゲン欠そ状態に おいて, レスベラトロールの摂取は肝臓の薬物代謝酵素 の遺伝子発現に影響を及ぼすことが明らかになった ${ }^{22)}$ 。

\section{N． 健康食品とレギュラトリーサイエンス}

レギュラトリーサイエンスとは，「科学技術の成果を人 と社会に役立てることを目的に，根拠に基づく的確な予 測, 評価, 判断を行い, 科学技術の成果を人と社会の調 和のうえで最も望ましい姿に調整するための科学」と定 義されている。筆者らは, これまでの研究により, 健康 食品素材の有効性評価及び健康影響評価に関する科学的 根拠を蓄積してきた。今般, 新たな機能性表示食品制度 が創設され，人びとの健康食品への関心が益々高まって きている。こうした状況の中, 健康食品の有効性評価及 び健康影響評価に関する研究は，レギュラトリーサイエ ンスの領域の中で引き続き重要な課題であると考えられ る。これらの研究は, 消費者の食の安全確保につながる ものである。

\section{謝 辞}

栄誉ある日本栄養改善学会賞の受賞に当たり, 選考委 員の先生方をはじめ, ご尽力いただきました学会関係者 の皆様に心より御礼申し上げます。またご指導いただき ました, 池上幸江先生, 斎藤衛郎先生, 山田和彦先生 （当時, 国立健康・栄養研究所）をはじめ, 共同研究者の 梅垣敬三先生, 点堅博士, 食品保健機能研究部諸氏（国 立健康 - 栄養研究所), 上原万里子先生 (東京農業大学), 太田篤扸先生（城西国際大学）他, 多くの共同研究者の 皆様に厚く御礼申し上げます。

\section{利益相反}

本研究の一部はフジッコ株式会社，大塚製薬佐賀栄養 製品研究所及び協和発酵キリン株式会社との共同研究に より実施されたものである。

\section{文献}

1) Cassidy, A., Bingham, S., Setchell, K.D.: Biological effects of a diet of soy protein rich in isoflavones on the menstrual cycle of premenopausal women, Am.J. Clin. Nutr., 60, 333-340 (1994)

2) Lu, L.J., Anderson, K.E., Grady, J.J., et al.: Effects of soya consumption for one month on steroid hormones in premenopausal women: implications for breast cancer risk reduction, Cancer Epidemiol Biomarkers Prev., 5, 63-70 (1996)

3) Arjmandi, B.H., Alekel, L., Hollis, B.W., et al.: Dietary soybean protein prevents bone loss in an ovariectomized rat model of osteoporosis, J. Nutr., 126, 161-167 (1996)

4) Ishimi, Y., Miyaura, C., Ohmura, M., et al.: Selective effects of genistein, a soybean isoflavone, on B-lymphopoiesis and bone loss caused by estrogen deficiency, Endocrinology, 140, 1893-1900 (1999)

5) Ishimi, Y., Arai, N., Wang, X.X., et al.: Difference in effective dosage of genistein on bone and uterus in ovariectomized mice, Biochem. Biophyis. Res. Commun., 274, 697-701 (2000)

6) Wu, J., Oka, J., Ezaki, J., et al.: Possible role of equol status in the effects of isoflavone on bone and fat mass in postmenopausal Japanese women: a double-blind randomized controlled trial, Menopause, 14, 866-874 (2007)

7) Wu, J., Oka, J., Higuchi, M., et al.: Cooperative effects of isoflavone and exercise on bone and lipid metabolism in postmenopausal Japanese women: a randomized placebocontrolled trial, Metabolism, 55, 423-433 (2006)

8）内閣府食品安全委員会：大豆イソフラボンを含む特定 保健用食品の安全性評価の基本的な考え方，内閣府食品 安全委員会報告書, https://www.fsc.go.jp/iken-bosyu/pc_ isoflavone180309_4.pdf（2006年 5 月）

9) Fujioka, M., Uehara, M., Wu, J., et al.: Equol, a metabolite of daizdein, Inhibits bone loss in ovariectomized mice, J. Nutr., 134, 2623-2627 (2004)

10）東泉裕子，梅木美樹，石見佳子，他：妊娠期 - 授乳期 の母親ラット，仔ラットに対するゲニステインとダイゼ イン投与における生体影響の相違, 栄養学雑誌, 64 , 161-172 (2006)

11) Tousen, Y., Ezaki, J., Fujii, Y., et al.: Natural S-equol decreased bone resorption in postmenopausal, equol nonproducing Japanese women: a pilot randomized placebocontrolled trial, Menopause, 18, 563-574 (2011)

12) Ueno, T., Abiru, Y., Uchiyama, S., et al.: Distribution of 24-hour urinary equol excretion as an indicator of the physiological range in healthy Japanese equol excretors, $J$. Funct. Food, 7, 129-135 (2014) 
13）石見佳子, 高野 史, 山内 淳, 他：「健康食品」中 の大豆イソフラボンの定量と表示に関する調査研究, 栄 養学雑誌， 67, 49-57 (2009)

14）谷中か抢る, 東泉裕子, 松本輝樹, 他:「健康食品」中 の大豆たんぱく質および大豆イソフラボンの定量と表示 に関する調査研究, 栄養学雑誌, 68, 234-241（2010）

15) Yanaka, K., Takebayashi, J., Ishimi, Y., et al.: Determination of 15 isoflavone isomers in soy foods and supplements by high-performance liquid chromatography, J. Agric. Food Chem., 60, 4012-4016 (2012)

16) Wu, J., Fujioka, M., Sugimoto, K., et al.: Assessment of effectiveness of oral administration of collagen peptide on bone metabolism in growing and mature rats, J. Bone Miner. Metab, 22, 547-553 (2004)

17) Ezaki, J., Hashimoto, M., Hosokawa, Y., et al.: Assessment of safety and efficacy of methylsulfonylmethane on bone and knee joints in osteoarthritis animal model, $J$. Bone Miner. Metab., 31, 16-25 (2013)

18) Ishimi, Y., Sugiyama, F., Ezaki, J., et al.: The effects of spirulina, blue-green alga, on bone metabolism in ovariectomized rats and hindlimb unloading mice, Biosci. Biotech. Biochem, 70, 363-368 (2006)

19) Koitaya, N., Ezaki, J., Nishimuta, M., et al.: Effect of low dose vitamin $\mathrm{K}_{2}$ (MK-4) supplementation on bio-indices in postmenopausal Japanese women, J. Nutr. Sci. Vitaminol., 55, 15-21 (2009)

20) Koitaya, N., Sekiguchi, M., Tousen, Y., et al.: Low-dose of vitamin $\mathrm{K}_{2}$ (MK-4) supplementation for 12 months improves bone metabolism and prevents forearm bone loss in postmenopausal Japanese women, J. Bone Miner. Metab., 32, 142-150 (2014)

21) Tsugawa, N., Shiraki, M., Suhara, Y., et al.: Vitamin K status of healthy Japanese women: age-related vitamin $\mathrm{K}$ requirement for gamma-carboxylation of osteocalcin, $\mathrm{Am}$. J. Clin. Nutr., 83, 380-386 (2006)

22）東泉裕子, 市田尚子, 西出依子, 他：レスベラトロー ルが閉経後早期モデルマウスの肝臓薬物代謝酵素遺伝子 発現に及ぼす影響，栄養学雑誌，72, 193-199（2014）

(受付：平成 28 年 6 月 1 日, 受理 : 平成 28 年 7 月 19 日) 


\title{
A Study on the Assessment of the Efficacy and the Health Effect of Health Food Ingredients
}

\author{
Yoshiko Ishimi \\ Department of Food Function and Labeling, National Institute of Health and Nutrition, \\ National Institutes of Biomedical Innovation, Health and Nutrition
}

\begin{abstract}
Purpose: Health foods have been used by consumers in their daily life. However, there are also products available on the market with poor scientific evidence for their efficacy and safety. From the point of view of food safety for consumers, we have evaluated the efficacy and safety of health food ingredients that are particularly relevant to the health of bones and knee joints.

Methods: Several health food ingredients were evaluated using an osteoporotic animal model. Some ingredients were evaluated in a randomized placebo-controlled trial in healthy postmenopausal Japanese women following approval by the institutional Research Ethics Committee.

Results: For soy isoflavones, it appeared that dose dependence differed in the effects on the reproductive organs from that of bone tissue in osteoporotic mice. Bone effects of isoflavones revealed a dependence on the production of equol, which is a gut bacterial metabolite of daidzein in healthy postmenopausal women. For vitamin $\mathrm{K}$ study, a suggested possibility was that vitamin $\mathrm{K}$ intake from daily meal was insufficient in healthy postmenopausal Japanese women in terms of preserving bone health; menaquinone-4 supplementation improved bone quality in these women. It was also demonstrated that excess intake of collagen peptide, methylsulfonylmethane, spirulina, and resveratrol should be avoided.

Discussion: Recently, a new food labeling system Foods with Function Claims has been established in Japan. Under these circumstances, research on the efficacy and health effects of health foods is yet considered to be important in terms of regulatory science. These studies would be on the leading edge with respect to consumer food safety.
\end{abstract}

Jpn. J. Nutr. Diet., 74 (5) 117 127 (2016)

Key words: Health foods, Food with Health Claims, efficacy assessment, health effect assessment, Regulatory science 